\title{
THE SUCCESS RATE OF ARTIFICIAL INSEMINATION USING LIQUID SEMEN WITH DIFFERENT DILUENTS IN BALI CATTLE
}

\author{
Hudiatma M. Dzikri \\ Postgraduate Study Program, Faculty of Animal Husbandry, University of Brawijaya, \\ Indonesia \\ Prasetiyo Dwi, Haryani Ety, Pujianto Jack \\ BPTU-HPT Denpasar Pulukan Breeding Center, Indonesia
}

Kuswati, Yekti Aulia Puspita Anugra, Susilawati Trinil, Lecturers

Faculty of Animal Husbandry, University of Brawijaya, Indonesia

*E-mail: ki.hudiatma@gmail.com

\begin{abstract}
Artificial insemination using liquid semen is beneficial for areas where liquid nitrogen is not available. The purpose of this study was to determine the success rate of artificial insemination using liquid semen with different diluents based on non-return rate (NRR) and conception rate (CR). Research location is at BPTU-HPT Denpasar Breeding Center Pulukan. The material used in this study is Bali cattle which have a Body Condition score (BCS) of 2.5-3 (scale 1-5), physically fit, not pregnant, no reproductive disorders. The method used in this study was experimental field 3 treatments and 20 replications. The number of cows used was 60 , each of which was treated 20 cows: $P O=A l$ using andromed diluent , P $1=$ Al using Tris aminomethane diluent $+20 \%$ egg yolk, P2 = Al using CEP-3 + $20 \%$ egg yolk diluent. Before conducting Al cows in estrus synchronization using PGF2 $\alpha$ (Enzaprost $-\mathrm{T}$ ) then in $\mathrm{Al}$ using liquid semen that is stored 1-3 days with an average motility of each treatment P0, P1, P2: $57 \pm 6,19 ; 60 \pm 5,65 ; 57 \pm 5,63$. Al uses a double dose at the second and eighth hour after estrus. The results of each treatment P0, P1 and P2 are NRR : $80 \%, 60 \%, 50 \%$; CR $=45 \%, 40 \%, 35 \%$. The conclusion of this study is that diluted andromed (P0) has a higher success rate when compared to P1 and P2.
\end{abstract}

\section{KEY WORDS}

Artificial insemination, liquid semen, non-return rate, conception rate.

Artificial Insemination using frozen semen has been used in Indonesia. Al with frozen semen requires liquid nitrogen for storage, not all regions in Indonesia have an adequate supply of liquid nitrogen, especially outside of Java. One alternative that can be used is to use liquid semen. Liquid semen is semen that is mixed with certain diluents and stored at 3$5^{\circ} \mathrm{C}$ (Susilawati and Yekti, 2018). Vishwanath and Shannon (2000) adds that the liquid semen storage of at least 2-4 days. The application of Al with liquid semen has been implemented in New Zealand because it has several advantages when compared to frozen semen (Yang, et al., 2018).

Diluent requirements that can be used for liquid semen are not toxic to spermatozoa, as an energy source, isotonic, as a buffer, inhibit bacteria, be able to protect spermatozoa and as cryoprotectants. In addition, liquid semen diluents must also be easily obtained and have a relatively cheap price (Susilawati and Yekti, 2018).

One of the most used diluent andromed. Andromed has the advantage in terms of fertility, is not easily contaminated with bacteria, easy to use (Susilawati, 2011). However, andromed is an imported product that takes a long time to order and has a high price. For this reason, several diluents have been developed that can maintain the survival of spermatozoa and increase the volume of semen. Verberckmoes et al (2005) developed a Cauda Epididymis Plasma (CEP) diluent that can maintain the life of spermatozoa for 6 days. 
Ducha et al (2012) said that CEP-2 $+20 \%$ egg yolk stored at $4-5^{\circ} \mathrm{C}$ can maintain spermatozoa membrane and motility for 8 days. Susilawati et al (2018) states that tris aminomethane + egg yolk and CEP + egg yolk can maintain the survival of spermatozoa better than using skim milk. For this reason, Tris $+20 \%$ EY and CEP-3 $+20 \%$ EY can be used as alternatives for liquid semen diluents, because they are easy to use and the ingredients are easily available.

Tris + $20 \%$ EY has a composition that is tris aminomethane, citric acid, lactose, fructose, streptomycin, penicillin, aquadest (Susilawati, 2011). Tris aminomethane and citric acid are used as buffer, lactose and fructose are useful as an energy source, streptomycin and penicillin function as anti-microbial, while the addition of egg yolk is used as cryoprotectant to keep spermatozoa during cold storage.

Cauda Epididymis Plasma (CEP-2) is a diluent that has a seminal plasma-like composition found in the epididymis. These conditions can maintain the quality of spermatozoa, membrane integrity and motility (Indriani et al., 2013; Purwoistri et al., 2013). CEP-3 + 20 EY is a modification of CEP-2 by replacing the expensive Bovine Serum Albumin (BSA) function with $0.4 \%$ egg white. The use of $0.4 \%$ egg whites can be used as a substitute for BSA in CEP-3 and can last up to 6 days in cold storage temperatures of $3-5^{\circ} \mathrm{C}$ (Sholikah, et al., 2016). Therefore, this study aims to determine the success rate of Al using liquid semen with different diluents in Bali cattle.

\section{MATERIALS AND METHODS}

This research was conducted on July 8 until November 7, 2019. The research location was at BPTU-HPT Denpasar Breeding Center Pulukan. The material used in this study were 60 Balinese cows that had a Body Condition score (BCS) of 2.5-3 (scale 1-5), physically fit, not pregnant, no reproductive disorders. cattle pen with semi intensive system. The feed given is king grass, indigofera and concentrate. Semen material used for liquid semen comes from a 4-year-old male weighing $\pm 450 \mathrm{~kg}$. Accommodated using an artificial vagina, liquid semen is stored in a ministraw containing $0.25 \mathrm{ml}$ (50 million sperm), liquid semen used for Al has motility above $40 \%$ (Table 2). Al and rectal palpation for pregnancy diagnosis are performed by officers who have attended training and are certified.

Table 1 - Composition of the Tris aminomethane $+20 \%$ EY and CEP-3 $+20 \%$ EY diluents

\begin{tabular}{|c|c|c|}
\hline Composition & Tris aminomethane $+20 \%$ EY & CEP-3 + 20\% EY diluent \\
\hline $\mathrm{NaCl}(\mathrm{g} / 100 \mathrm{ml})$ & - & $0,09 \mathrm{~g}$ \\
\hline $\mathrm{KCl}(\mathrm{g} / 100 \mathrm{ml})$ & - & $0,05 \mathrm{~g}$ \\
\hline $\mathrm{CaCl}_{2}\left(\mathrm{H}_{2} \mathrm{O}\right)_{2}(\mathrm{~g} / 100 \mathrm{ml})$ & - & $0,04 \mathrm{~g}$ \\
\hline $\mathrm{MgCl}_{2}\left(\mathrm{H}_{2} \mathrm{O}\right)_{2}(\mathrm{~g} / 100 \mathrm{ml})$ & - & $0,08 \mathrm{~g}$ \\
\hline $\mathrm{NaHCO}_{3}(\mathrm{~g} / 100 \mathrm{ml})$ & - & $0,10 \mathrm{~g}$ \\
\hline $\mathrm{NaH}_{2} \mathrm{PO}_{4}(\mathrm{~g} / 100 \mathrm{ml})$ & - & $0,11 \mathrm{~g}$ \\
\hline $\mathrm{KH}_{2} \mathrm{PO}_{4}(\mathrm{~g} / 100 \mathrm{ml})$ & - & $0,27 \mathrm{~g}$ \\
\hline Fructose $(\mathrm{g} / 100 \mathrm{ml})$ & $0,500 \mathrm{~g}$ & $0,27 \mathrm{~g}$ \\
\hline Lactose $(\mathrm{g} / 100 \mathrm{ml})$ & $1,500 \mathrm{~g}$ & - \\
\hline Tris $(\mathrm{g} / 100 \mathrm{ml})$ & $1,363 \mathrm{~g}$ & $1,61 \mathrm{~g}$ \\
\hline Citric acid $(\mathrm{g} / 100 \mathrm{ml})$ & $0,762 \mathrm{~g}$ & $0,82 \mathrm{~g}$ \\
\hline Penicilin $(\mathrm{g} / 100 \mathrm{ml})$ & $0,100 \mathrm{~g}$ & $0,009 \mathrm{~g}$ \\
\hline Streptomycin $(\mathrm{g} / 100 \mathrm{ml})$ & $0,100 \mathrm{~g}$ & 0,01 \\
\hline Egg yolk $(\mathrm{g} / 100 \mathrm{ml})$ & $20 \%$ & $20 \%$ \\
\hline Egg white $(\mathrm{g} / 100 \mathrm{ml})$ & - & $0,4 \%$ \\
\hline
\end{tabular}

Andromed contains aquabidest, fructose, glyserol, citric acid, buffer, phosfolipid, spectynomycine, lincomycine, tylocin, gentamycine, but the exact composition of the andromed diluents is not available for publication. The making of andromed diluents is as follows, by mixing andromed with aquabides in a ratio of $1: 4$, then homogeneous and ready to use (Susilawati, 2011).

Semen that has been accommodated is tested for quality macroscopically and microscopically. then the dilution process is carried out through 3 stages: the first stage is a 
mixture of semen with diluent (ratio $1: 1$ at $37^{\circ} \mathrm{C}$ ) then cooled in the refrigerator. the second stage at $25^{\circ} \mathrm{C}\left(50 \%\right.$ of the remaining diluent to be added) and the third stage at $20^{\circ} \mathrm{C}$ after that it waits until the temperature is $3-5^{\circ} \mathrm{C}$ then motility after dilution is tested.

The method used in this study was experimental, with 3 treatments and 20 replications. Cattle used were 60 cows, each of which treated 20 cows, $\mathrm{PO}=\mathrm{Al}$ with andromed diluent, $\mathrm{P} 1=\mathrm{Al}$ with Tris aminomethane diluent $+20 \%$ egg yolk, P2 $=$ Al with CEP diluent $-3+20 \%$ egg yolk.

Bali cattle synchronized estrus with 2-time injection techniques. The hormone PGF2 $\alpha$ (Enzaprost-T) used for 1 injection is $5 \mathrm{ml}$. Detection of estrus is done through visual observations through observations on the vulva that is swollen, red (color), warm, mucous discharge, and mounting other cattle. Artificial insemination is carried out with a double dose of $\mathrm{Al}$ at the second and eighth hour after estrus.

The observed variables are non-return rate (NRR-1) on the 21 st day after $\mathrm{Al}$ and conception rate $(\mathrm{CR})$.

1. Non Return Rate (NRR). Non return rate is a percentage of the number of Al acceptors that are not estrus after the Al. Animals that did not estrus again after Al assumed that the cattle were pregnant (Jainudeen and Hafez. 2008).

$$
\frac{\text { the number of cattle that are not show estrus again }}{\text { the number of all cattle in } \mathrm{AI}} \times 100 \%
$$

2. Conception Rate (CR). Conception rate is the percentage of cows that are pregnant at the first Al (Susilawati, 2011). Detection of pregnant cows using the rectal palpation method.

$$
\frac{\text { the number of cattle pregnant at the first AI }}{\text { the number of all cattle in AI }} \times 100 \%
$$

The data obtained were tabulated using Microsoft Excel by finding the average value, then analyzed descriptively (Harsojuwono, et al., 2011). For supporting variables namely the quantity of cervical mucus, vulva color, vaginal temperature were analyzed by the Kruskal wallis test and if there were differences, Mann Whitney continued testing.

\section{RESULTS AND DISCUSSION}

Semen quality before AI in this research had a motility percentage of P0 $57 \pm 6,19$; $\mathrm{P} 160 \pm 5,65$; P2 $57 \pm 5,63$ (Table 2). The motility value of semen before $\mathrm{Al}$ is in accordance with Standart Nasional Indonesia (SNI) (minimum 40\%).

Table 2 - Semen motility before Al

\begin{tabular}{|c|c|}
\hline Treatments & Motility (\%) \\
\hline P0 & $57 \pm 6,19$ \\
\hline P1 & $60 \pm 5,65$ \\
\hline P2 & $57 \pm 5,63$ \\
\hline
\end{tabular}

Table 3 - Success Rate Al

\begin{tabular}{|c|c|c|c|c|c|}
\hline \multirow{2}{*}{ Treatments } & \multirow{2}{*}{ Number of Al acceptors } & \multicolumn{2}{|c|}{ NRR } & \multicolumn{2}{|c|}{ CR (\%) } \\
\cline { 3 - 6 } & & Number of cattle & $\%$ & Number of cattle & $\%$ \\
\hline P0 & 20 & 16 & 80 & 9 & 45 \\
\hline P1 & 20 & 12 & 60 & 8 & 40 \\
\hline P2 & 20 & 10 & 50 & 7 & 35 \\
\hline
\end{tabular}

Note: PO - Andromed diluents; $P 1$ - Tris aminomethane diluent $+20 \% E Y ; P 2-C E P-3$ diluent $+20 \% E Y$.

Non return rate (NRR) is one method for estimating pregnancy in cattle. Varotto, et al (2016) states that NRR is an indicator of animal fertility and can be used to evaluate reproductive performance quickly without waiting for birth. NRR observations can be seen in 
Table 3. Based on the Table, descriptively it is known that the highest NRR value is at P0: $80 \%$ with the number of cows assumed to be pregnant as many as 16 , while the lowest value at $\mathrm{P} 250 \%$ assuming 10 pregnant animals.

NRR value $\mathrm{P} 2$ and $\mathrm{P} 1$ in this study was lower than in previous studies in cattle PO, which is $81.48 \%$ (CEP-3 $+20 \mathrm{EY}$ ) and $81.48 \%$ (Tris aminomethane $+20 \mathrm{EY})$. The low value of NRR in this study believed to be caused by various factors, one of which is a factor of estrus synchronization. Chao et al. (2010) explained that the synchronization of estrus can affect the intensity of estrus. Kurykin et al. (2003) also argue, there is a tendency for signs of weak estrus in cattle which are synchronized using two PGF2 $\alpha$ injections. In addition, environmental factors such as the presence of a lactating can also be suspected to influence the success of the pregnancy. Islam (2011) states that the process of lactating can cause hormonal responses that can inhibit the emergence of estrus Aji, et al. (2017) states that lactating cattle will have an impact on the process of implantation in the uterus. lactating cattle have a higher likelihood of premature embryo death (Jousan et al., 2005). In addition, environmental factors such as the presence of lactating cattle can also be suspected to influence the success of the pregnancy. Islam (2011) states that the process of breastfeeding can cause hormonal responses that can inhibit the emergence of estrus. Aji et al. (2017) states that lactating cattle will have an impact on the process of implantation in the uterus. Lactating cattle have a higher likelihood of premature embryo death (Jousan et al., 2005).

Conception rate (CR) in this study was determined by using rectal palpation to detect pregnancy, so that it can be known more accurately. The highest CR value was in the P0: $45 \%$ treatment and the lowest was in the P2: 35\% treatment. CR values in P1 and P2 that are lower than P0, may be caused by the quality of the diluent. In P1 (Tris aminomethane) and P2 (CEP-3) they contain egg yolk which is a product of livestock production. The product, consists of several components which cannot be standardized in quality and are varied, so that some components can have beneficial effects but some other components can also have adverse effects on spermatozoa function (Ratnawati, et al., 2017). whereas in PO (andromed) is a thinner media without egg yolk and does not contain ingredients from animals so there is no risk of microbiological contamination. One of the composition of andromed which acts as cryoprotectant is glycerol. Glycerol is a substance that can diffuse into spermatozoa cells and can be metabolized into an energy source and form fructose (Susilawati, 2011). Papa et al. (2015) states that the use of diluent containing $7 \%$ glycerol in liquid semen can increase pregnancy percentage greater when compared with diluent without glycerol.

The CR value of treatment P1 $40 \%$ and P2 35\% in this study was lower than in previous studies in Ongole cattle, namely Tris aminomethane + 20\% EY 83.3\%; 59.26\% (Costa et al., 2016; Saifudin et al., 2018) and CEP-3 + 20\% EY 51.85\% (Salim et al., 2018). The low CR value can be caused by a variety of factors, one of which is the quality of the semen used at the time of the Al, however, the motility of the semen used in this study is in accordance with SNI which is above $40 \%$ (Table 2.) so that the factors that are likely to influence the low $\mathrm{CR}$ value is an Al acceptor factor. Poor estrus quality can be suspected to be a factor causing low CR values. Roelofs et al (2010) also stated that there was a tendency to decrease the accuracy of estrus detection after the use of the prostaglandin hormone. The low estrous response might be influenced by individual factors in responding to the given PGF2 $\alpha$ hormone. The immature corpus luteum does not have PGF2 $\alpha$ receptors so that the induction of luteolysis with PGF2 $\alpha$ fails (Balumbi, et al., 2019). The estrus quality of each treatment can be seen in Table 4.

Table 4 - Scores of cervical mucus quantity, vulva color, vaginal temperature and vulvar swelling

\begin{tabular}{|c|c|c|c|c|}
\hline Treatments & $\begin{array}{c}\text { Scores of cervical mucus quantity } \\
*\end{array}$ & $\begin{array}{c}\text { Vulva color } \\
* *\end{array}$ & $\begin{array}{c}\text { Vaginal temperature } \\
\left({ }^{\circ} \mathrm{C}\right)\end{array}$ & $\begin{array}{c}\text { vulva swelling\% } \\
(\mathrm{n})\end{array}$ \\
\hline P0 & $2,30 \pm 0,64^{\mathrm{b}}$ & $2,10 \pm 0,51^{\mathrm{a}}$ & $38,96 \pm 0,40^{\mathrm{a}}$ & $100(20$ ekor $)$ \\
\hline P1 & $1,80 \pm 0,56^{\mathrm{a}}$ & $2,05 \pm 0,45^{\mathrm{a}}$ & $38,72 \pm 0,62^{\mathrm{a}}$ & $100(20 \mathrm{ekor})$ \\
\hline P2 & $1,82 \pm 0,54^{\mathrm{a}}$ & $2,12 \pm 0,40^{\mathrm{a}}$ & $38,70 \pm 0,46^{\mathrm{a}}$ & $100(20$ ekor $)$ \\
\hline
\end{tabular}

Note: * score of cervical mucus quantity: 1 = low/absent; 2 = moderate; 3 = abundant; ${ }^{* *}$ vulva color score: $1=$ pale pink; 2 = pink; 3 = red. 
Based on the kruskall wallis test it is known that the quantity score of cervical mucus has a significant difference $(P<0.05)$. The score of cervical mucus quantity in treatments $P 1$ and $P 2$ was significantly different $(P<0.05)$ with $P 0$. However, $P 1$ treatment was not significantly different from $\mathrm{P} 2$. The highest average score of cervical mucus quantity was at P0 $2.30 \pm 0.64$ while the lowest was at P1 $1.80 \pm 0.56$. Vulva color, vaginal temperature there was no significant difference $(p>0.05)$ in the two treatments. vulvar swelling occurs in all $\mathrm{Al}$ acceptors used in each treatment. a high Scores of cervical mucus quantity value at P0 can also be indicated that the response of estrus quality to the Al acceptor in the treatment is higher when compared to P1 and P2. Cervical mucus can function as a facilitator for spermatozoa to reach the ovum so that fertilization occurs (Berardi et al., 2015). Verma et al (2014) states that when cervical mucus has an influence on the value of conception in cattle. The appearance of cervical mucus can be used as an indicator of reproductive health related to estrous behavior and can be used as a sign to determine the exact time of artificial insemination, and the appearance of cervical mucus will increase the conception rate (Ondho et al., 2019). The quantity of cervical mucus is influenced by hormones estradiol produced by follicles. When estrous hormone estradiol is at its peak, it will trigger an increase in $\mathrm{LH}$, resulting in ovulation and stimulation of cervical mucus discharge (Jainudeen and Hafez, 2008). In addition, other factors such as the condition of livestock, individuals, activities and interactions in livestock also affect the intensity of estrus (Kune and Najamudin, 2002).

\section{CONCLUSION}

The success rate of Al liquid semen using andromed (P0) (80\% NRR, 45\% CR) diluent is higher than Tris aminomethane (P1) $60 \%$ NRR, 40\% CR) and CEP-3 (P2) (50\%) diluents NRR, 35\% CR).

\section{ACKNOWLEDGMENTS}

Authors express their gratitude to the Ministry of Education that has provided research funding and breeding center of Bali cattle in Bali, Indonesia.

\section{REFERENCES}

1. Aji, R., Panjono, A. Agus, B. P. Widyobroto, T. Hartatik, I. G. S. Budisatria, Ismaya and S. Bintara. 2017. Kinerja Reproduksi Sapi Betina Sumba Ongole yang Di Inseminasi dengan Semen Beku Sapi Jantan Belgian Blue. Buletin Peternakan. 41(4): 379 - 384.

2. Balumbi, M., I. Supriatna and M. A. Setiadi. 2019. Response and Characteristics of Estrous after Estrous Synchronization with Cloprostenol In Friesian Holstein Cow. Acta Veterinaria Indonesiana. 7(1): 29-36. Indonesian.

3. Bernardi, S., A. Rinaudo and P. Marini. 2016. Cervical mucus characteristics and hormonal status at insemination of Holstein cows. Iranian J. Vet. Res. 17(1):45-49.

4. Chao, L. M., S. Sato., K Yoshida., Y Kawano., T. Kojima and C. Kubota. 2010. Comparison of Oestrous Intensity between Natural Oestrus and Oestrus Induced with Ovsynch Based Treatments in Japanese Black Cows. Reprod Dom Anim. 45: 168-170.

5. Costa, N. D., T. Susilawati., N. Isnaini , and M. N. Ihsan. 2016. The Difference of Artificial Insemination Successful Rate of Onggole Filial Cattle Using Cold Semen with Different Storage Time with Tris Aminomethane Egg Yolk Dilution Agent. Journal of Pharmacy. 6(6): 13-19.

6. Harsojuwono, B. A., I. W. Arnata and G. A. K. D. Puspawati. 2011. Rancangan Percobaan. Teori, Aplikasi SPSS and Excel. Malang.

7. Indriani., T. Susilawati., S. Wahyuningsih. 2013. Daya Hidup Spermatozoa Sapi Limousin yang Dipreservasi dengan Metode Water Jacket and Free Water Jacket. Jurnal Veteriner. 14(3): 379-386.

8. Islam, R. 2011. Synchronization of Estrus in Cattle: A Review. J. Veternary World. 4(3):136-141. 
9. Jainudeen, M.R and E.S.E. Hafez. 2008. Pregnancy Diagnosis. In Reproduction in Farm Animals. 7th ed. Blackwell Publishing. 405-430.

10. Jousan, F. D., M. Drost and P. J. Hansen. 2005. Factors Associated With Early and MidTo-Late Fetal Loss In Lactating An Non Lactating Holstein Cattle In a Hot Climate. J. Anim. Sci,. 83: $1017-1022$.

11. Kune, P. and Najamudin. 2002. Respon Estru Sapi Potong Akibat Pemberian Progesteron, Prostaglandin PGF2 $\alpha$ and Estradiol Benzoat dalam Kegiatan Sinkronisasi Estrus. Jurnal Agroland. 9 (4): $380-384$.

12. Kurykin, J., U. Jaakma., L. Majas., M. Jalakas., M. Aidnik., A. Waldmann and P. Padrik. 2003. Fixed Time Deep Intracornual Insemination of Heifers at Synchronized Estrus. Theriogenology. 60: 1261-1268.

13. Ondho, Y. S., F. A. Akbar., D. A. Lestari and D. Samsudewa. 2019. Level of Sodium Chloride $(\mathrm{NaCl})$ and Profile of Cervical Mucus of Dairy Cattle At Various Age Synchronized by Prostaglandine. J. Indonesian Trop. Anim. Agric. 44(4): 364-371.

14. Papa, P. M., R. D. Maziero., P. N. Guasti., C. R. Junqueira., C. P. Freitas-Dell'Aqua., F. O. Papa., F. P. Vianna., M. A. Alvarenga., A. M. Crespilho., 2015. Effect of Glycerol on the Viability and Fertility of Cooled Bovine Semen. Theriogenology. 08: 107-113.

15. Purwoistri, R. T., T. Susilawati, and S. Rahayu. 2013. Kualitas Spermatozoa Hasil Sexing Menggunakan Pengencer Andromed and Cauda Epididymal Plasma-2 (CEP-2) Ditambah Kuning Telur 10\%. Jurnal kedokteran hewan, 7(2): 116- 119.

16. Ratnawati, D., N. Isnaini and T. Susilawati. 2017. Pemanfaatan Casa dalam Observasi Motilitas Spermatozoa Semen Cair Sapi Madura dalam Pengencer Berbeda. Jurnal IImuIlmu Peternakan. 27 (1): 80 - 95.

17. Roelofs J., F. Lopez-Gatius, R.H.F. Hunter, F.J.C.M. van Everdenburg, 2010. When is a cow in estrus? Clinical and practical aspects: Review. Theriogenology. 74: 327-344.

18. Saifudin, M., N. Isnaini., A. P. A.Yekti and T. Susilawati. 2018. Tingkat Keberhasilan Inseminasi Buatan Menggunakan Semen Cair Menggunakan Media Pengencer Tris Aminomethan Kuning Telur Pada Sapi Persilangan Ongole. 19 (1): 60-65.

19. Salim, A., A. P. A.Yekti., Kuswati and T. Susilawati. 2018. Perbedaan Keberhasilan Inseminasi Buatan Menggunakan Semen Beku and Semen Cair Menggunakan Pengencer CEP-3 + Kuning Telur pada Sapi Persilangan Ongole. Journal of Tropical Animal Production. 19 (1): 66-72.

20. Sholikah, N., N. Isnaini., A. P. A. Yekti, \& T. Susilawati. 2016. Pengaruh penggantianBovine Serum Albumin (BSA) dengan putih telur pada pengencer CEP-2 terhadap kualitas semen sapi Peranakan Ongole pada suhu penyimpanan $3-5^{\circ} \mathrm{C}$. Jurnal Ilmu-IImu Peternakan. 26(1), 7-15.

21. Sulistyowati, D., M. A. Faris., A. P. A. Yekti., S. Wahjuningsih and T. Susilawati. 2018. Kualitas Semen Cair Sapi Peranakan Ongole pada Pengencer Tris Aminomethan Kuning Telur Tanpa Raffinosa yang Disimpan pada Media yang Berbeda Suhu. Journal of Tropical Animal Production. 19(1):38-45.

22. Susilawati, T. 2011. Spermatology. UB Press. Malang.

23. Susilawati, T. and A. P. A. Yekti. 2018. Teknologi inseminasi buatan menggunakan semen cair (liquid semen). Malang.

24. Susilawati, T.,D. Ratnawati., N. Isnaini., Kuswati And A. P. A. Yekti. 2018. Character of Liquid Semen Motility in Various Diluents on Balinese Cattle during Cold Storage. Asian Jr. of Microbiol. Biotech. Env. Sc. 20(1): 166-172.

25. Verberckmoes, S. et al, 2004. Storage of fresh bovine semen in diluent based on the ionic composition of cauda epididymal plasma. J. Reprod. Dom. Anim. 39 (6): 1-7.

26. Verma KK, Prasad S, Kumaresan A, Mohanty TK, Layek SS, Patbandha TK, Chand S. 2014. Characterization of physico-chemical properties of cervical mucus in relation to parity and conception rate in Murrah buffaloes. Veterinary World. 7: 467-471.

27. Vishwanath, R., and P. Shannon. 2000. Storage of bovine semen in liquid and frozen state. Anim. Reprod. Sci. 62: 23-53.

28. Yang, D.H. et al, 2018. Application of Liquid Semen Technology under the Seasonal Dairy Production System in New Zealand. Animal Reproduction Science. 0378-4320: 1-9. 